\title{
Téoros
}

Revue de recherche en tourisme

\section{The Tourist Multiplier}

\section{Brian Archer et John E. Fletcher}

Volume 7, numéro 3, novembre 1988

Économie du tourisme

URI : https://id.erudit.org/iderudit/1080377ar

DOI : https://doi.org/10.7202/1080377ar

Aller au sommaire du numéro

\section{Éditeur(s)}

Université du Québec à Montréal

ISSN

0712-8657 (imprimé)

1923-2705 (numérique)

Découvrir la revue

Citer cet article

Archer, B. \& Fletcher, J. E. (1988). The Tourist Multiplier. Téoros, 7(3), 6-9.

https://doi.org/10.7202/1080377ar d'utilisation que vous pouvez consulter en ligne.

https://apropos.erudit.org/fr/usagers/politique-dutilisation/ 


\section{The tourist Multiplier}

Multiplier analysis has probably been more misused than any other economic technique. Its apparent simplicity has attracted many non-specialists, whose bizarre findings have misled practitioners and detracted from the useful studies undertaken by others. An account of the state-of-the-art in the late 1970"s is given in Tourism Multipliers: The State of the $A r^{(1)}$. Since then, further studies have added to the general understanding and knowledge of tourism multipliers as a technique for evaluating the economic benefits of tourism and a policy tool.

The purpose of this paper is to examine the nature of tourism multipliers, their uses, strengths, weaknesses and limitations, together with an examination of the part which they can play in policy-making and planning.

\section{What is a tourism multiplier?}

A tourism multiplier measures the relationship between an injection of tourist expenditure into an economy and the amount of economic activity which is created by this expenditure. Such multipliers can be used to measure the resultant changes in business transactions, business output, income levels, government revenue, foreign exchange and employment levels. Unfortunately, the nature and the policy implications of these different types of multipliers have been confused by some writers. The situation has been further compounded by the introduction of another so-called multiplier - the ratio multiplier, which has no basis in economic theory and few practical uses. Before considering the nature of these different types of multipliers and the relationships between them, it is necessary to consider the multiplier mechanism at work.

Tourism expenditure is an invisible export in the sense that it creates a flow of foreign currency into the destination country. In a similar manner, domestic tourism creates a flow of outside expenditure into the economy of a region within a country. This expenditure creates additional business revenue. household income, employment, public sector revenue and import requirements.

\footnotetext{
* Professors, Department of Management Studies for the Tourism and Hotel Industries, University of Surrey, England,
}

For example, if an additional $\$ 1$ million of tourist expenditure is received, this forms $\$ 1$ million of additional direct revenue to the business sector of the economy. It is a fallacy to assume, as many writers have done, that all of this additional revenue forms income to the resident population. The hoteliers, shop-keepers and others who receive this revenue must replenish their stocks and inventories in order to provide for future sales, they must maintain their property and equipment, they may be required to pay various taxes, licences and other fees to the public sector, buy electricity, gas and water and pay insurance premiums and other payments of various private sector organizations.

Furthermore, a proportion of the profits and wages and salaries may leak out of the sys. tem and fail to generate further economic activity if some of the shareholders and workers do not permanently reside in the area in question. The money which remains within the economy flows through the system in three principal ways.

First, tourist establishments pay out wages and salaries to their workforce and earn profits. This creates income within the area. Secondly, some of the goods and services required by the tourist establishments are purchased from local suppliers whose turnover is thereby increased. Thirdly, as already mentioned, some money is paid as public sector revenue in the form of taxes, duties and fees.

The individuals, local business firms and public sector authorities themselves re-spend some, or all, of this money and, in so doing, set in motion further rounds of economic activity. This chain reaction of economic activity continues through successive rounds of spending, diminishing in magnitude during each round as money leaks out of the system as savings or imports. The general output of the area increases (assuming that sufficient resources are available), incomes and public sector revenue rise and employment opportunities increase.

The relative size and importance of these indirect effects are governed by the extent to which business firms within the economy are able to supply each other with the necessary goods and services (inter-industrial linkages) and, in consequence, the degree to which items have to be imported from outside the economic system. Generally, the larger the economy, the more likely it is that local establishments will be able to supply most of the goods and services required. Conversely, the smaller the economy, the more probable it is that imports will be needed, especially to replace machinery and other capital goods.

Figure 1 shows the tourist income multipliers for a number of selected countries/regions. It should be noted that the value of the income multiplier tends to be relatively low in the smaller countries/regions compared with the larger countries/regions.

Incomes in the area will rise, not only the direct effects of tourist expenditure, but also from the general increase in economic activity which this expenditure generates. In consequence, consumer expenditure increases and itself generates further business turnover. These induced effects can be very large and, in some regions, can create greater economic activity than the direct effects alone.

Together, the indirect and induced effects are called the secondary effects. The tourism multiplier is a measurement of the total effects (direct plus secondary) created by additional tourism expenditure.

The flow of tourism expenditure in the case of The Bahamas is illustrated in Figure $2^{(2)}$. The left hand unshaded block represents an additional $\$ 100$ of tourist expenditure received as revenue by business establishments in the economy. This revenue is shown as being re-spent in four ways: $\$ 3$ goes to the public sector as taxes, duties and licenses. $\$ 43$ is paid to business establishments in The Bahamas to replenish stocks, etc., $\$ 31$ forms income to residents of The Bahamas (in the form of wages, salaries, rent, dividends and distributed profits) a further $\$ 5$ of this amount goes to the public sector as import duties, wharfage fees, etc, and $\$ 18$ is spent on purchasing goods and services outside the economy. The net leakage out of the economy during this first round of expenditure is $\$ 13$.

In the second round, therefore, the public sector receives $\$ 8$ which it re-spends ( $\$ 3$ in purchasing local supplies, $\$ 4$ on wages and salaries and $\$ 1$ on imports); local businesses receive $\$ 43$ which is re-spent ( $\$ 7$ to the public sector, $\$ 15$ in purchases from other local businesses, $\$ 13$ on wages, salaries. 
FIGURE I

Tourist income multipliers

(country / region identification is shown in key)

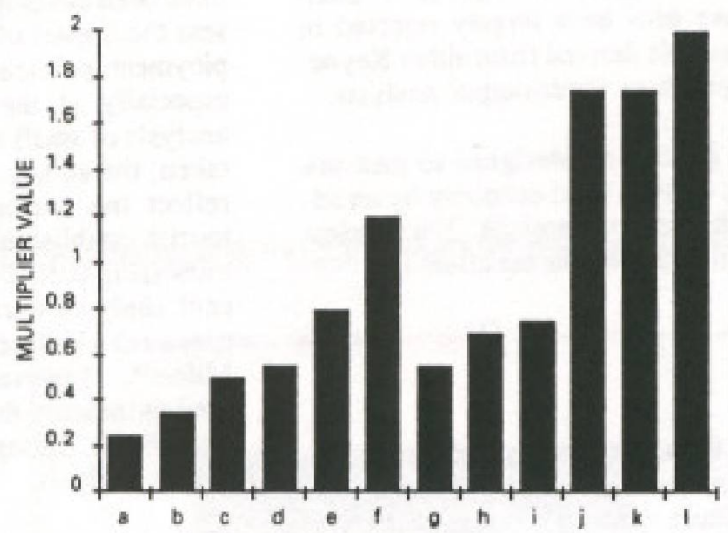

\section{COUNTRY/ AEGION}

KEY Small rogions a: S.E. Dorset. UK b. S.W. England. UK c: Victoria Met Area, B.C.

Lave Regions

d: Door County, Wisconsin, USA

Tourist islands

g. Gibralta

n: Fiji

: The Bahamas

e: Missouri State_USA

Nonthera lieland, UK

Langer Couniries

c: United Kinge

i: Turkey

FIGURE 2

The Floor of the Tourist Dollar in Bahamas

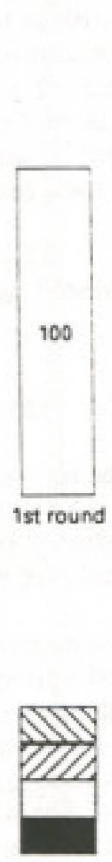

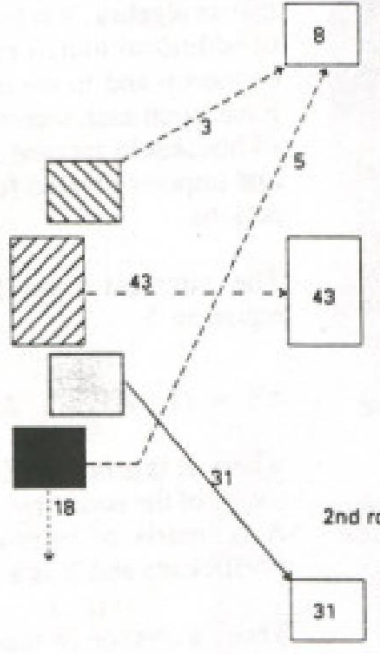
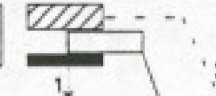

Govemment revenue

Local business transactions

Household income

import leakages rent, dividends and distributed profits etc., and $\$ 8$ on imported goods and services); and local households receive $\$ 31$ which is respent ( $\$ 24$ on consumer expenditure, $\$ 3$ on rènt and wages, $\$ 4$ on holidays, education overseas, etc.). Leakages in the second round total $\$ 13$ and the amount of monies remaining in the economy to generate further economic activity is $\$ 69$.

In the third round the public sector receives $\$ 7$ which is re-spent ( $\$ 6$ within the economy and $\$ 1$ on imported goods and services); the business sectors receive $\$ 42$ of which $\$ 20$ is spent on imports and $\$ 22$ remains in the economy and the household sector receives $\$ 20$, of which $\$ 3$ is spent abroad and $\$ 17$ stays within The Bahamas. Thus, leakages in the third round have risen to $\$ 24$, but $\$ 45$ re-circulates into a fourth round of income/output generation. This process continues through successive rounds of expenditure with the leakages diminishing the economic impact at each stage, until the amount of monies remaining within the system becomes negligible.

It is difficult to put a time-scale on these flows because some purchases may be made immediately, whilst others may be deferred several months. In The Bahamas, for instance, up to four of five rounds of economic activity are largely completed within twelve months of the initial expenditure with the remaining (much smaller) rounds taking up to a further year to complete.

The technique used to measure these flows is called a multiplier model. Four types of multiplier are in regular use and serious confusion seems to have been caused by their misuse and the inappropriate applications by some researchers.

A Transactions (or Sales) Multiplier measures the amount of business turnover created by additional tourist spending. Somewhat similar to this is the output mulriplier which measures the additional level of output achieved in the economy as a result of the same tourist spending. The principal difference between these two multipliers is that the output multipliers take account, not only of the level of transactions, but also of any changes which occur in the level of inventories.

An Income Multiplier measures the increase in the level of income in the economy created by the additional tourist expenditure. Income can be measured either as national income (regional in the case of domestic tourism) or as disposable income, i.e. the income which is actually available to the households for their expenditures or savings. However, in both cases the income accruing to non-nationals who are resident in the area must be extracted because the incomes they receive are not benefits to the area. On the other hand, the secondary economic effects of the re-spending of non-nationals' income within the area must be included wi= thin the calculations. 
An Employment Multiplier is a measurement of either the amount of employment generated per additional unit of tourist expenditure, or the ratio of the total employment generated by tourism to the direct employment alone. Although a useful source of information, the employment multiplier is probably one of the most tenuous multipliers and great care is needed when such mul= tipliers are interpreted. The major problems are:

a) in most studies, employment is assumed to have a linear relationship with either income or output. The evidence which is available suggests that this relationship should be non-linear. Both ad hoc and input-output multiplier models can be constructed with non-linear employment coefficients, but, in practice, this is rarely done;

b) the multiplier models assume that the employment in each sector is fully utilized so that any additional output demands will require additional employment inputs - this is clearly not the case and quite often additional demand can be satisfied without increasing the labour force. Also, it is not necessarily true that if there is a reduction in the level of tourist expenditure then there would automatically be a reduction in the number of persons employed. The results of employment multipliers are best interpreted as an indication of the number of (normally full-time equivalent) job opportunities supported by tourism expenditure.

These multipliers are elosely related to each other. Thus, for example, in the case of The Bahamas, additional tourist spending of $\$ 100$ in 1980 created approximately $\$ 225$ of business turnover, $\$ 88$ of local income and 0.006 full-time equivalent job opportunities after all rounds of expenditure were completed. The transactions multiplier, therefore, was $225 / 100=2.25$; the income multiplier was $88 / 100=0.88$; and the employment multiplier was 0.00006 . The available data where not sufficient to compute the output multiplier.

A Ratio Multiplier measures the ratio of the total income generated to the direct (firstround) income generated alone. In the case of The Bahamas, for example, the ratio income multiplier would be $88 / 31=2.84$ and the ratio employment multiplier would have been 2.47 . It is difficult to imagine any practical use for such multipliers. In essence they are an expression of the amount of intersectoral business linkages in the economy, i.e. the larger the ratio multiplier, the greater are the linkages within the system.

\section{Methods of Measurement}

Four principal techniques are used to measure the value of the multiplier.

Base Theory Models, which are rarely used

these days, postulate that a stable relationship exists between export sectors, such as tourism, and local sectors with the result that changes in the level of tourist expenditure create measurable and predictable changes in the level of local economic activities. A brief account of the principles of base theory models is given in Archer ${ }^{31}$. Such models have now been largely rejected in favour of models derived from either Keynesian multipliers or input-output analysis.

Keynesian Madels are designed to measure the income created in an economy by an additional unit of export eamings. The simplest formulation is shown in equation 1 .

\section{leakages}

where 1 is the additional unit of tourist expenditure and leakages are the proportion of this expenditure which goes into savings and imporis. A long-run formulation of this model, which takes into account the effects of investment, is shown in equation 2.

1

leakages-investment

A typical, simplified, Keynesian short-run model is shown in equation 3. The same model can be converted into a long-run model by subtracting the marginal propensity to invest from the value of the denominator.

$$
\frac{1}{1=c\left(1-t_{j}\right)\left(1-t_{d}-b\right)+m}
$$

where $\mathrm{c}$ is the marginal propensity to consume, ti is the marginal rate of indirect taxation and other deductions; td is the marginal rate of direct taxation and other deductions; $b$ is the marginal rate of transfer payments and $\mathrm{m}$ is the marginal propensity to import.

For practical analysis, however, this model is over-simplified and takes no account of the different forms and magnitudes of leakages during each round of transactions. Even the more detailed Keynesian models developed for some studies cannot provide the wealth of information required for policy-making and planning. A practical solution is to use ad hoc models.

Ad Hoc Models, derived partly from the Keynesian formulation, can be constructed specifically for the analysis required. The simplest formulation of an ad hoc model is shown in equation $4^{44}$.

$$
A \times \frac{1}{1-B C}
$$

where $A$ is the proportion of additional tourist expenditure remaining in the economy after the first round of leakages, B is the propensity of local people to spend in the local economy and $\mathrm{C}$ is the proportion of expenditure by local people that accrues as income within the economy.

Again, this model is over-simplified for practical purposes and more advanced models have been developed and used widely to assess the impact of tourism on incomes, employment, public sector revenue and imports, especially at the regional level ${ }^{(5)}$. When analysis of small economies is being undertaken, the ad hoc model can be modified to reflect the various impacts generated by tourist establishments of differing size and ownership nature (local or overseas). A recent study of tourism in the Cook Islands uses such a differential multiplier approach, Milne $^{(b)}$. However, the principal method used to measure the magnitude of the secondary flows through an economy is inputoutput analysis.

Inpul-Output analysis involves preparing a table which shows the economy of the destination country, or region, in matrix form. The table is similar to a set of national (or regional) income accounts except for the level of detail and its emphasis upon final demand. Within the table, each sector of the economy is shown (in the vertical columns) as a purchaser of goods and services from other sectors in the economy and from factors of production and imports. Therefore, each sector is also shown (in the horizontal rows) as a seller of intermediate goods and services to each other sector, and a seller of final goods to households, fixed capital formation and exports.

Exports, including tourist expenditure, are part of final demand and are, therefore, shown as injections of money into the system. Imports and savings are shown as leakages out of the system. By the use of simple matrix algebra, it is possible to trace the flow of additional tourist expenditure through the economy and to measure the impact which it has upon each sector, as well as the amount of household income, public sector revenue and imports created for each round of transactions.

The simplest formulation ${ }^{27}$ is shown in equation 5.

$$
\Delta \mathrm{X}=(\mathrm{I}-\mathrm{A})^{-1} \quad \Delta \mathrm{Y}
$$

where $X$ is a factor of the total sales of each sector of the economy, I is an identity matrix, $\mathrm{A}$ is matrix of inter-industry transactions" coefficients and $\mathrm{Y}$ is a vector of export sales.

Thus, a change in tourist expenditure $(\Delta \mathrm{Y})$ creates, through increased activity within the economy, a change in the output and sales of each sector $(\Delta \mathrm{X})$. Sub-models are required to calculate the effects on income, public sector revenue and imports. Again, the above model is over-simplified for practical application and more advanced models must be constructed to analyze real-life situations ${ }^{(8)}$. 
Some of the major advantages associated with the use of input-output modelling to determine the economic impact of tourism are: first, comprehensiveness - the model can be as detailed as research time and resources will allow and therefore, cover every facet of economic activity; tourism, being a personal service, is labour intensive and the production functions of tourist establishments tend to be fairly stable over time. This is particularly useful from the point of view of input-output analysis because of the use of average technical coefficients and the required assumption of linear homogeneous production functions. For a more through discussion about the application of inputoutput analysis to a service-based economy. see Fletcher and Snee ${ }^{(9)}$. Secondly, flexibility, an input-output model constructed for the express purpose of studying tourism impact can be constructed in a manner which provides the most lucid insight to the effects of tourist expenditure. Models have been constructed in such detail that they distinguish between expenditure on theatres, cinemas, bull fights, different categories of accomodation, etc. ${ }^{101}$ and tourist expenditure can be disaggregated into a number of different classifications to evaluate the economic benefits of different types of tourist activity. A study of Jamaica in 1984 used 27 different categories of tourist arrivals in order to assess the importance of each type(11).

Input-output models are expensive and timeconsuming to compile. Good up-to-date data are needed for each sector of the economy. Skill and experience are needed to operate the model and interpret the results.

It has been suggested that linear programming may offer an alternative methodology for determining the economic impact of tourism expenditure, Kottke ${ }^{(12)}$. Linear programming can be used to maximize or minimize a particular policy objective, such as maximizing the level of local income from tourism activity but, on its own, does not provide a comprehensive method for determining the economic impact of tourism. It is more suited to the normative issues such as, What would be the optimum mix of different types of tourist establishments if we wish to maximize local income? In this respect it cannot complete with input-output analysis when trying to estimate the economic impact of tourism as it is. Furthermore, there is no reason why the normative questions cannot be answered by applying linear programming to the input-output model ${ }^{133}$.

\section{Weaknesses and Limitations of Multiplier Analysis}

Despite the usefulness of multiplier analysis, there are several problems which must be overcome.

First, data are rarely available to compile a detailed model of the economy. Input-output analysis, in particular, requires complete, or nearly complete data for all sectors of the economy. Sectors where data are inadequate have to be aggregated with a consequent loss in overall accuracy.

Tourism expenditure data may be inaccurate or insufficiently disaggregated to use in a detailed model. Where an economy already has an up-to-date input-output model it may be the case that the construction of the model is not suitable for analyzing the impact of tourism expenditure. It is important that the models used to determine the impact of tourism should be specifically constructed for the task $\mathrm{k}^{(14)}$.

Secondly, most multiplier models assume that any additional tourist expenditure which occurs generates exactly the same impact on the economy as previous tourist expenditure. More sophisticated models remove this oversimplification.

Thirdly, the majority of multiplier models assume that sufficient spare capacity exists throughout the economy to meet the demands generated by additional tourist expenditure. Thus, increased tourist expenditure results in increased business tumover, income, public sector revenue, etc. In some sectors, however, capacity may already be fully utilized and there may not be any unemployed or under-employed labour available. In such cases, especially in the short-run, further expenditure creates inflation and some of the extra goods and services required to meet the increased tourist demand have to be imported. The increased propensity to import from this additional tourist expenditure will not be reflected in the multiplier models which are generally constructed on the basis of average values rather than marginal values. As a consequence of this, the multiplier values will overestimate the impact of the additional tourist spending.

Some more recent multiplier models have taken this into account by including the capacity utilization of each sector in order to determine the ability of the economy to absorb further tourism expenditure. For instance, Wanhill ${ }^{(15)}$ constructed a matrix of sectoral capacity constraints which funnelled the effects of further demand into the impor sector(s) when it was felt that full capacity of individual sectors was reached. The imposition of capacity constraints can significantly influence the size of the multipliers.

\section{Tourist Multipliers for Policy Making}

All of the multiplier models, with the exception of the ratio multiplier, provide information which is useful to policy makers and planners. It is of some importance to know just how much income, employment, government revenue and foreign exchange is created by tourism. However, the inputoutput technique provides an exceptional amount of information concerning, not only the economic benefits of tourism, but also the structure of the economy as a whole, the degree of sectoral dependency (both in terms of forward and backward linkages), the existence of potential supply constraints which may damage the development of tourism and the economic benefits to be derived from further development. Additionally, the inputoutput technique permits the policy makers to explore the What if....? questions that are so important when drawing up development plans. $f$

\section{Notes explieative:}

(1) ARCHER, B.H. Tourism Multipliers: The State of the Art, University of Wales Press, Carditt, 1977

(2) Figure 2 is based upon some work undertaken in The Bahamas, see ARCHER, B.H., The Touris: Dollar: Its Impect on Incomes and Emplorment in The Bahamas. Government of The Bahamas. Nassau, 1981. For purposes of exposition, the diagram is simplified. In particular, leakages into saw. ings have been omitted. Also, in most economies. payments from the household sector , in the form of income taxes, etc., would be significant, but in The Bahamas such payments are minimal because there is no income tax.

(3) Op. cit., pp. 14-16.

(4) See CLAWSON, Marian and KNETSCH, Jack L. The Economics of Outdoor Recreation. John Hopkins, 1966, pp. $241 \cdot 242$.

(5) For a description of some practical ad hoe models, see ARCHER, op, cit., pp. 21-26.

(6) MILNE, S.S., Differential Multiphers, Annals of Tourism Research, Vol. 14, 1987, pp. 499.515.

(7) The derivation of this model is explained in LEONTIEF, W., Input- Output Eeonomies, Oxford University Press, New York, 1966.

(8) For a more detailed explanation of more advanced input-putput multipliers, see ARCHER, op. cit.. pp. $26-32$.

(9) FLETCHEA John E and SNEE, Helena R., InputOutput Analysis and the Service Industries. Service Industries Journal, vol, 2, No 1, 1965.

110) For example, see Input-Output Table of the Spanish Tourism Economy. Spanish Institute of Tourism, 1978

(11) FLETCHER, John E., The Eeonomic Impact of international Tourism on the National Economy of Jamaiea. 1984. This work was undertaken for the Government of dlamaica and was organised by the WTO/UNDP and financed by USAID

[12] KOTTKE, Marvin, Estimating Economic /mpacts of Tourism, Annals of Tourism Research, Vol. 15. 1968. pp. 122-133.

(13) For a more detailed discussion about the use of Finear programming in input-output analysis, see $O^{\prime}$ CONNOR, R, and HENAY, E.W, Input-Output Analysis and its Applications. Griffin's Statistical Monographs, No 36, 1975

(14) For a discussion concerning the difficulties associated with applying a "standard" existing input. output model, see Determination of the Impor. tance of Tourism as an Economic Activity within the Framework of the National Accounting System, World Tourism Organization. Fitth Session, New Dellhi. October 1983.

(15) WANHILL. Stephen R.C., Tourism Multiphers Under Capaciv Constrainis, Service Industries Journal. Vol, 8. No 2, 1989, pp. 136-142. 